\title{
Early effects of gossypol on the testis and epididymis in the rat
}

Christine RADIGUE, J. C. SOUFIR, Marie-Louise COUVILLERS, Marie-Claude DANTEC $\left({ }^{*}\right)$, R. FOLLIOT $\left({ }^{*}\right)$

Biologie cellulaire, Faculté de Médecine 94275 Kremlin-Bicêtre Cedex

(*) Biologie de la Reproduction, Faculté des Sciences, 2, avenue du Général-Leclerc, 35042 Rennes Cedex.

Summary. In a previous study we showed that the administration of gossypol to rats for 34 days caused 2 types of modification of the epididymis: (1) the secretion of carnitine and inositol were reduced in the fluid, (2) the spermatozoa lost their motility and showed major morphological changes (head-flagella dissociation). We wished to clarify the early effects of gossypol on the epididymis. Sprague Dawley adult rats $(350 \mathrm{~g})$ were forced fed with gossypol at a dose of $25 \mathrm{mg} / \mathrm{kg} /$ day for 17 days. After sacrifice, the motility of spermatozoa from the cauda of the epididymis was measured and the morphology of spermatozoa from the caput of the epidydimis quantified following electron microscopic examination. Carnitine, inositol and potassium were assayed in the epididymal fluid. No abnormalities of spermatozoa (motility, count, morphology, ultrastructural examination) were observed in the cauda of the epididymis. In contrast, a high percentage $(63 \%)$ of spermatozoa from the caput of the epididymis were altered (vacuolization and lysis of mitochondria). Biochemical analysis of the fluid revealed no differences between treated animals and controls.

Thus it appeared therefore, that after 17 days of gossypol administration, the only abnormality detected in the epididymis involved the spermatozoa from the caput. It is therefore probable that the motility disorders seen in spermatozoa from the cauda of the epididymis at 34 days cannot be explained by alterations of the secretion of fluid but rather by earlier direct lesions of testicular spermatids and/or of spermatozoa from the caput of the epididymis.

\section{Introduction.}

In a previous study our group showed that the administration of gossypol to adult rats $(350 \mathrm{~g})$ for 34 days caused major modifications of the biochemical composition of the epididymis. Although the concentrations of the major components which contribute to the structural integrity of the epididymal epithelium (protein, lactate dehydrogenase - LDH, acid phophatase) did not differ from those of the controls, there was a large, dose dependent reduction of the secreted elements in the epididymal fluid (carnitine, inositol) (Soufir et al., 1984 ; Jegou et al., 1985). These results have since been confirmed by another 
team (Giridharan et al., 1987). In parallel we also confirmed that in the cauda of the epididymis, the number of spermatozoa is reduced, their aptitude for movement lost and that they undergo major morphological alterations (headflagella dissociation) (Hoffer, 1983).

Furthermore, a group of morphologists analysed the 2 principal types of ultrastructural abnormalities of spermatozoa in the epididymis and considered that one variety (mitochondrial) was formed in the testis whereas the second (axonemal) was only produced in the epididymis. They suggested that the latter, which consisted in the disappearance of the dense fibers and doublets 4 to 7 (called hemiaxoneme) was due to a direct effect of gossypol on the epididymis (Baccetti et al., 1986). The results of biochemical and morphological analyses therefore raised the question of the relationship between spermatozoal abnormalities, especially of the epididymal type, and modifications in the composition of epididymal fluid. It is known that several epididymal secretion components influence the maturation of spermatozoa. In particular carnitine enables them to form a rapidly mobilizable energy reserve (Jeulin et al., 1987). It was tempting to assume that a major reduction in carnitine could lead to the disorganization of spermatozoal structures.

We explored this hypothesis by investigating whether the epididymal secretory deficiency preceded the spermatozoal lesions. We chose to study the effects of a short treatment, 17 days, as this is the period in which the so called "epididymal " hemiaxonemes are the largest in the caput of the epididymis. The biochemical composition of epididymal fluid was analysed and morphological abnormalities of epididymal sperm were quantified. The study was completed by a quantitative examination of abnormalities of the germinal cells in the testes.

\section{Materials and methods.}

\section{1 - Animals and treatment.}

Sprague-Dawley adult rats, $350 \mathrm{~g}$ (IFFA Credo, L'Arbresle, France) were kept in conditions in which water and food were constantly available. Five rats were treated by gavage with $25 \mathrm{mg} / \mathrm{kg} /$ day of gossypol (Leiras Pharmaceutical, Turku, Finland) dissolved in sesame oil, 6 days a week for 17 days. A fresh suspension of gossypol was made each day and the gavage performed while the solution was under constant agitation. Five control rats received an equal volume of solvent. At the end of treatment the animals were decapitated and the testes and epididymides dissected.

\section{$2-$ Methods}

2.1. Measurement of motility. - A drop of fluid from the cauda of the epididymis was placed in the well of a cavity slide containing $0.2 \mathrm{ml}$ of medium at $37^{\circ}$. The medium, which was developed in our laboratory, was derived from B2 medium (Ménézo, 1976). The composition is shown in table 1. The percentage of motile spermatozoa was measured immediately with a light microscope (Nachet 200) at low magnification $(\times 100)$. 
TABLE 1

Composition of the medium used for the study of motility $(\mathrm{g} / 100 \mathrm{ml})$.

\begin{tabular}{ll}
\hline $\mathrm{NaCl}$ & \\
$\mathrm{NaHCO}$ & 0.525 \\
$\mathrm{KCl}$ & 0.250 \\
$\mathrm{MgSO}_{4} \cdot 7 \mathrm{H}_{2} \mathrm{O}$ & 0.080 \\
$\mathrm{KH}_{2} \mathrm{PO}_{4}$ & 0.020 \\
$\mathrm{Na}_{4}$ acetate & 0.006 \\
Ca lactate & 0.005 \\
Na pyruvate & 0.050 \\
Bovine serum albumin & 0.025 \\
Glucose & 1 \\
\hline
\end{tabular}

2.2. Light and e/ectron microscope study. - For the investigation of morphology, a drop of fluid was diluted in $0.5 \mathrm{ml}$ of Tyrode solution then spread out on a slide by tipping. After fixation in ether alcohol $(\mathrm{v} / \mathrm{v})$ for $1 \mathrm{~h}$, the preparation was stained using Shorr's hematoxylin technique. It was observed under a Univar microscope at magnifications of $\times 400$ and $\times 1000$. For the ultrastructural study, fragments of testis, caput and cauda of the epididymis were fixed in glutaraldehyde $(2.5 \%)$ in cacodylate buffer $0.1 \mathrm{mmol} / 1, \mathrm{pH} 7.2$, then in a solution of osmic acid (1\%).

Small cubes of tissue were then sampled, dehydrated in ethanol and embedded in araldite. Ultrafine sections were obtained using an ultramicrotome (Reichert OMU 3). They were contrasted with uranyl acetate and lead citrate then examined with an electron microscope (Elmiskop CT 150 Siemens) at magnifications from 20000 to 35000 . The ultrastructural study was performed in a quantitative manner. One hundred mid pieces (ip) and 100 principal pieces (pp) were counted in each batch, in 2 control and 2 treated rats. The percentage of ip and $\mathrm{pp}$ abnormalities was calculated.

2.3. The spermatocrit. - The following parameters were measured after centrifugation of epididymal fluid in a heparinized microcapillary:

- the height of the pellet, corresponding to the spermatozoa and cellular debris (V1) :

- the height of the supernatant, corresponding to the volume of epididymal plasma (V2) ;

- the ratio V1/V2 + V1 "spermatocrit" was calculated and expressed as a percentage.

2.4. Assays. - These measurements were performed in fluid from the caput and the cauda of the epididymis, centrifuged in a capillary microtube. The epididymal plasma (supernatant) was recovered and diluted to $1 / 30$ in distilled water.

2.4.1. Free L-carnitine. - Carnitine was measured using the technique described by Pearson et al. (1974). The final concentration in the reaction medium was the following: 
- Hepes buffer $0.125 \mathrm{~mol} / \mathrm{I}, \mathrm{pH} 7.4$;

- DTNB (5-5' dithiobis 2 nitrobenzoic acid) $0.25 \mathrm{mmol} / \mathrm{l}$;

- Acetylcoenzyme A $0.187 \mathrm{mmol} / \mathrm{l}$;

- Acetylcarnitine transferase $13 \mathrm{U} / \mathrm{ml}$.

The volume of the fluid sample from the caput of the epididymis was $0.2 \mathrm{ml}$ and from the cauda $0.02 \mathrm{ml}$, for a total volume in the cuvet of $0.6 \mathrm{ml}$.

The reaction took place at room temperature and was read on an Eppendorf $1101 \mathrm{M}$ photometer at $405 \mathrm{~nm}$.

2.4.2. Inositol. - Inositol was measured using the technique of Weissbach (1974). The final concentration in the reaction medium was the following:

- Sodium carbonate buffer $0.156 \mathrm{~mol} / \mathrm{l}, \mathrm{pH} 9.5$;

- NAD 3,125 mmol/l ;

- Inositol dehydrogenase $0.25 \mathrm{U} / \mathrm{ml}$.

The volume of the fluid sample from the cauda was $0.050 \mathrm{ml}$ for a total volume in the cuvet of $0.270 \mathrm{ml}$.

The reduction reaction of NAD to NADH occurred at room temperature and was read at $366 \mathrm{~nm}$.

2.4.3. Potassium. - Potassium was measured by the potentiometric technique using a Beckman selective electrode. The apparatus was calibrated to measure a range of concentrations between 1 and $10 \mathrm{mmol} / \mathrm{l}$.

2.4.4. Standard statistical procedures ( $T$ test) were used.

\section{Results.}

1 - Biochemical composition of the fluid (table 2).

The concentration of the 2 components, carnitine and potassium, was measured in fluid from the caput and cauda of the epididymis. A third component, inositol, was only measured in fluid from the cauda.

TABLE 2

Effects of gossypol ( $25 \mathrm{mg} / \mathrm{kg}$ for 17 days) on the composition of epidydimal fluid ( $\mu \mathrm{mol} / \mathrm{ml})$.

\begin{tabular}{lcc}
\hline & Controls (5) & Gossypol (5) \\
\hline $\begin{array}{l}\text { Carnitine : } \\
\text { Caput }\end{array}$ & $1.2 \pm 0.44$ & $1.4 \pm 0.25$ \\
Cauda & $27.12 \pm 6$ & $23.36 \pm 5.19$ \\
$\begin{array}{l}\text { Potassium : } \\
\text { Caput }\end{array}$ & $10.38 \pm 1.41$ & $12.75 \pm 1.41$ \\
Cauda & $20.7 \pm 3.30$ & $20.61 \pm 1.68$ \\
Inositol : & $28.68 \pm 1.85$ & $33.12 \pm 5.46$ \\
Cauda & & \\
\hline
\end{tabular}

() : Number of animals. mean \pm SEM 
In both the treated and control animals, the concentration of carnitine and potassium was higher in the cauda than in the caput (carnitine 18 fold, $K 2$ fold) but there was no significant difference between the 2 batches of animals. Similarly the concentration of inositol in the cauda fluid was not modified by the treatment.

\section{2 - Spermatozoa from the cauda of the epididymis (fig. $1 \mathrm{~A}, \mathrm{~B}$ ).}

2.1. Motility. - There was no reduction in the number of motile spermatozoa. In our conditions of observation, the percentage of motile cells was : $79 \pm 7$ in the controls $(n=5)$ versus $80 \pm 9$ in the treated animals $(n=5)$.

2.2. Morphology. - After treating the smear with Shorr's staining, the same morphological profile was apparent in both the control and treated animals. Ninety-five percent of the spermatozoa appeared to be normal. In 2 cases, we observed the presence of $5 \%$ of decapitated spermatozoa.

According to the electron microscope in treated animals the hemiaxonemes (characterized by the disappearance of dense fibres 4 to 7 and the corresponding microtubule doublets), were present in $4 \%$ of the flagellae at the level of their principal piece (fig. $1 \mathrm{Bb}^{*}$ ). At the level of the mid pieces none of the mitochondria was altered (fig. 1Aa) in control and treated samples.

2.3. Spermatocrit. - There was no difference in the number of spermatozoa, indirectly estimated by measurement of the spermatocrit, between fontrol and treated animals : $45 \pm 3$ versus $50 \pm 3 \%$ (mean \pm SEM).

\section{3 - Spermatozoa from the caput of the epididymis (fig. 1C).}

In treated animals, mitochondrial alterations were found in $63 \%$ of the spermatozoa. The mitochondria appeared vacuolized, increased in size, and the cristae had disappeared. Between 2 and 4 mitochondria were affected in each transverse section of the mid piece examined (fig. 1C2). The mitochondrial lesions were sometimes even more pronounced : all the mitochondria were lyzed and it was only possible to see the axoneme, the dense fibres and the plasma membrane (fig. 1C3). More rarely, even the plasma membrane had disappeared (fig. 1 C4). It is notable that hemiaxonemes were never observed and the absence or displacement of the dense fibres was never recorded (fig. 1C5).

\section{4 - Testicular germinal cel/s (fig. 1D).}

In treated animals, among all elements of the germinal line only the late spermatids were damaged (fig. 1D1). As in the case of spermatozoa from the caput of the epididymis, the lesions did not involve the axoneme and were entirely localized in the mitochondria (fig. 1D1). The predominant abnormality consisted of vacuolization of these mitochondria. However, the number of damaged mitochondria per mid piece section was lower than that observed for spermatozoa from the caput of the epididymis (approximately 1 to 2 ). Forty percent of elongated spermatids were damaged. 


\section{Discussion - Conclusion.}

The profile of the lesions induced at the level of the epididymis by a short duration of gossypol administration (17 days) appeared quite different from those resulting from 34 days of treatment. After a 34-day treatment, we observed a reduction in epididymal secretion, a complete immobilization and very numerous breakages of spermatozoa from the cauda of the epididymis.

After 17 days the study of epididymal secretion in its different forms: the synthesis (inositol), uptake (carnitine), ionic exchange (potassium), showed that none of these processes were disturbed. Furthermore, the motility and morphology of spermatozoa from the cauda were mostly not modified. In contrast, in the caput of the epididymis, a high percentage of spermatozoa (63\%) showed cellular lesions localized in the mitochondria (vacuolization and sometimes lysis). Exceptionally, complete disappearance of the plasma membrane was seen.

Our results differ appreciably from those in the literature (Oko et al., 1982; Baccetti et al., 1986 ; Hoffer et al., 1983). Although the authors all agree that there is no major modification of spermatozoa from the cauda of the epididymis at 17 days, their observations of spermatozoa from the caput of the epididymis are discordant. Hoffer et al. (1983) only recorded the appearance of abnormalities after 21 days of treatment, Oko et al. (1982) only found 2 to $3 \%$ percent of spermatozoa with mitochondrial lesions and finally Baccetti et al. (1986) noted the presence of $25 \%$ of axonemal abnormalities (hemiaxoneme) and $25 \%$ of mitochondrial abnormalties. These differences can probably be explained by the different experimental conditions: gossypol derived from different sources (Soufir et al., unpublished), dissolved in a variety of vehicles (propylene glycol, bicarbonate buffer, oil), administered by different routes (subcutaneous injection, gavage) and the age of the rats. Mature rats (70 days) were used in most studies but younger rats (52 days) in the study of Baccetti et al. (1986).

There is also a disagreement between authors as regards the target organ(s) for gossypol : epididymis and testis (Baccetti et al., 1986) or testis alone (Oko et al., 1982; Hoffer et al., 1983). We have not enough data to join this debate.

The purpose of the present investigation, was to study the relationship between modifications of epididymal secretion and spermatozoal abnormalities and we were able to demonstrate that the spermatozoal lesions precede the reduction in epididymal secretion. Our results show that the primary lesion induced by gossypol involves the mitochondria of elongated spermatids and the spermatozoa from the caput of the epididymis. To survive, these cells utilize an

FIG. 1. - Ultrastructural study of the germinal cells after 17 days of gossypol treatment.

$A$ and $B$ : Cauda of epididymis. Transverse sections of the mid ( $\mathrm{Aa}$ ) and principal pieces (Ab, Bb). Mid pieces are represented by the symbol a, principal pieces by $b$. The mid pieces are never altered, the mitochondria are normal. Hemiaxonemes $\left(b^{*}\right)$ are exceptionally present at the level of the principal pieces.

$\mathrm{C}$ : Caput of epididymis. Transverse sections of the mid and principal pieces.

1. 2: Vacuolized mitochondria; 3: Lysed mitochondria; 4 : Lysed mitochondria and plasma membrane ; 5 : Unchanged principal piece.

D : Testis. Transverse sections of the mid pieces of late spermatids.

${ }^{*}$ : Cytoplasm of the spermatids. 

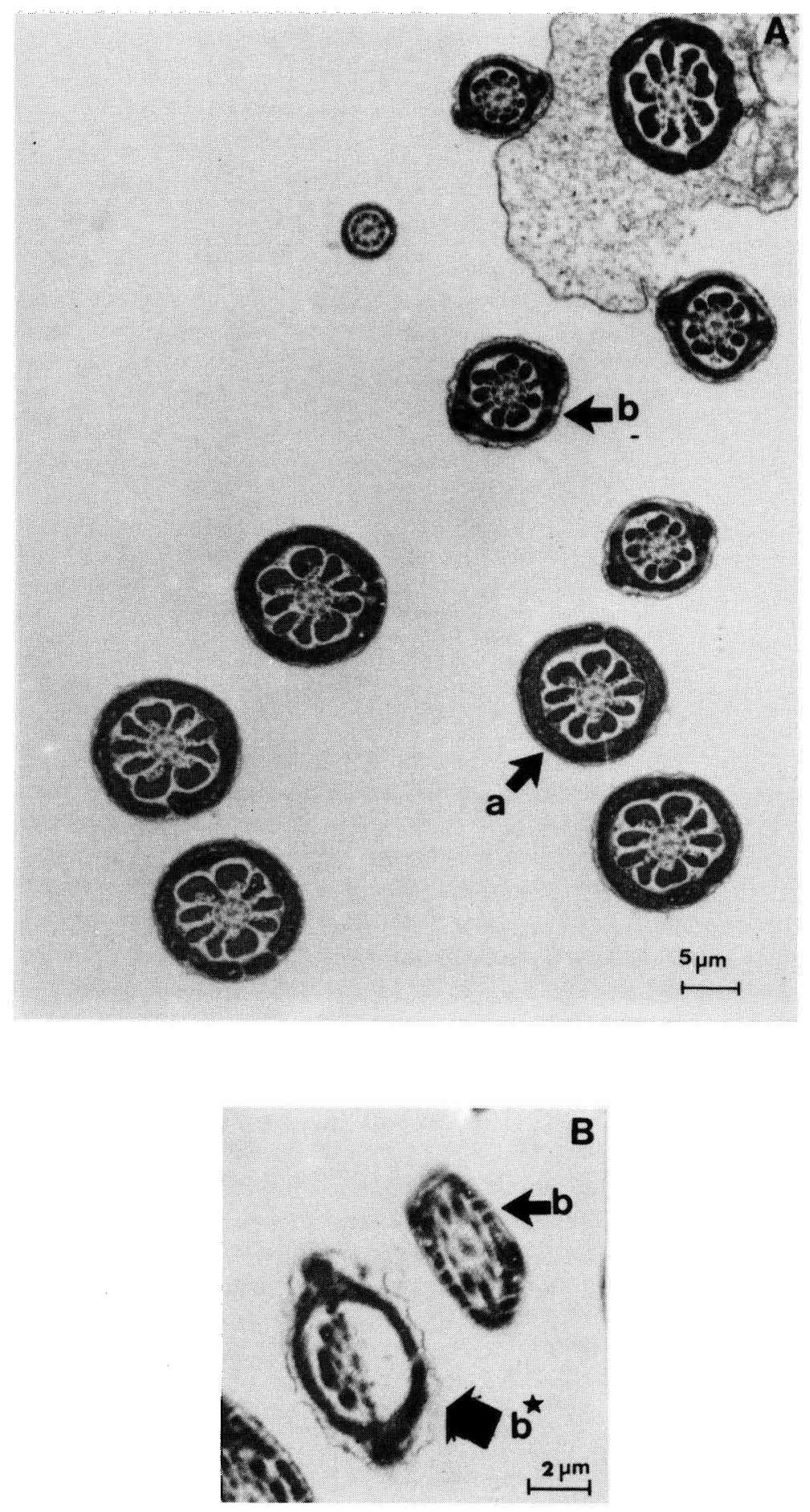

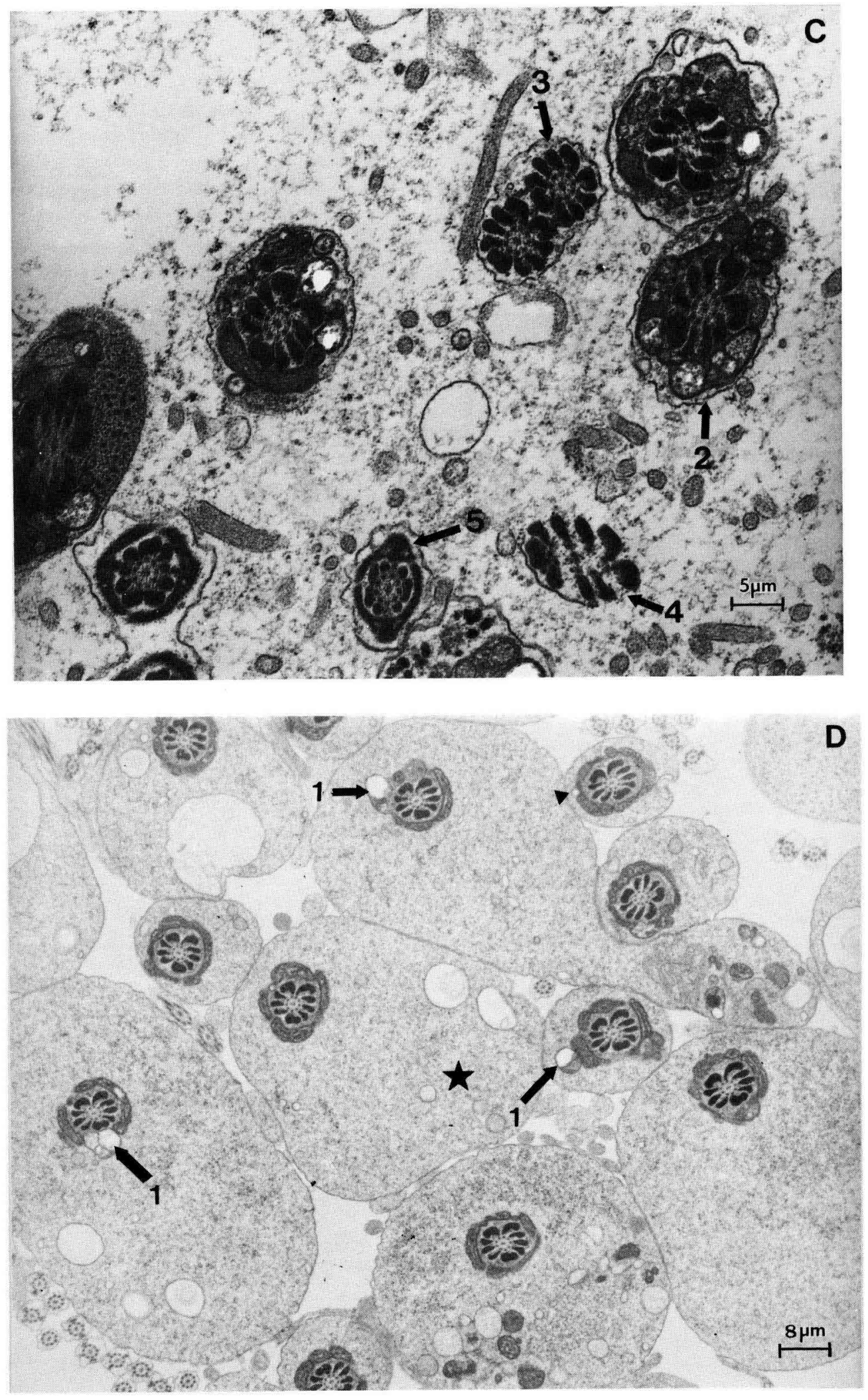
oxidative type metabolism, using as substrates pyruvate provided by the Sertoli cell (Grootegoed et den Boer, 1987), lactate produced by the epididymal epithelium or endogenous lipids (Hafez et al., 1976). The development of a mitochondrial disorder therefore leads to an inability of the cell to use these substrates, a deficit of ATP and cell death. Furthermore, this same metabolic scenario is suggested by in vitro investigations performed on human spermatozoa as well as other flagellated cells (Druez et al., submitted for publication).

The significance of the reduction in epididymal secretion remains obscure. It is possible that investigation of factors controlling the epididymal function, either locally (in situ secretion of testosterone, ABP, production of testicular fluid) or at a distance (plasma testosterone and aldosterone) (Hinton and Keffer, 1985), may provide the information necessary to explain this phenomenon.

$5^{\mathrm{e}}$ Congrès de la Société d'Andrologie de langue française, Paris, décembre 1987.

Acknow/edgements. - We are grateful to Mr P. Etre for the photographic work Madame C. Baraise for the typing, and Dr R. G. Forman for the English translation.

Résumé. Effets du gossypo/ sur le testicule et l'épididyme de rat.

L'administration de gossypol à des rats pendant 34 jours entraîne deux types de modifications au niveau de l'épididyme: 1 ) dans le fluide, les sécrétions de carnitine et d'inositol sont réduites, 2) les spermatozoïdes perdent leur mobilité et présentent d'importantes modifications morphologiques (dissociation tête-flagelle).

Nous avons cherché à préciser les effets précoces du gossypol sur l'épididyme. Des rats adultes Sprague Dawley $(350 \mathrm{~g})$ ont été gavés avec du gossypol à la dose de $25 \mathrm{mg} / \mathrm{kg} / \mathrm{j}$ durant 17 jours. Après sacrifice, la mobilité des spermatozoïdes de la queue de l'épididyme a été mesurée, la morphologie des spermatozoïdes de la tête a été quantifiée après examen en microscopie électronique. Dans le fluide épididymaire ont été dosés la carnitine, l'inositol et le potassium. Dans la queue, on n'observe aucune anomalie des spermatozoïdes (mobilité, numération, morphologie, examen ultrastructural). Par contre, au niveau de la tête épididymaire, les spermatozoïdes présentent un pourcentage élevé (63\%) d'altérations (vacuolisation et lyse des mitochondries). L'étude biochimique du fluide ne montre aucune différence avec celle réalisée chez les témoins.

II apparaît donc qu'après une administration de 17 jours de gossypol la seule anomalie décelée dans l'épididyme intéresse les spermatozoïdes de la tête. II est donc probable que le trouble de la mobilité des spermatozoïdes épididymaires de la queue observé à 34 jours n'est pas expliqué par la modification de la sécrétion du fluide mais par des lésions directes plus précoces des spermatides testiculaires et/ou des spermatozoïdes épididymaires de la tête.

\section{References}

BACCETTI B., BIGLIARDI E., BURRINI A. G., RENIERI T., SELMI G., 1986. The action of Gossypol on rat germinal cells. Gamete Res., 13, 1-17.

DRUEZ D., MARANO F., CALVAYRAC R., VOLOCHINE B., SOUFIR J. C. Effect of gossypol on the morphology, motility and metabolism of a flagellated protist, Dunaliella bioculata (soumis à publication) 
GIRIDHARAN N., SESIKERAN B., BAMJI M. S., MADHYASTHA M. N., 1987. Dose and time related changes in LDH-X activity, epididymal carnitine levels and fertility, in gossypoltreated male rats. Contraception, 35, 89-100.

GROOTEGOED J. A., den BOER P. J., 1987. Energy metabolism of spermatids. Proc. WHO-FHI Symp. on Golgi, lysosome and centriole events in early spermiogenesis : targets for male fertility regulation. Mexico, 11-13 march 1987 (in press).

HAFEZ E. S. E., PRASAD M. R. N., 1976. Functional aspects of the epididymis, 31-41. In HAFEZ E.S.E., Human semen and fertility regulation in men. The C.V. Mosby Co. Saint-Louis

HINTON B. T., KEFFER D. A., 1985. Binding of $(3 \mathrm{H})$ aldosterone to a single population of cells within the rat epididymis. J. Steroid Biochem., 23, 231-233.

HOFFER A. P., 1982. Ultrastructural studies of spermatozoa and the epithelial lining of the epididymis and vas deferens in rats treated with gossypol. Arch. Androl., 8, 233-246.

HOFFER A. P., 1983. Effects of gossypol on the seminiferous epithelium in the rat. Biol. Reprod., 28. 1007-1020.

JEGOU B., DANTEC M. C., SOUFIR J. C., STELLY N., ANDRÉ J., GARNIER D. H., VIGUIERMARTINEZ M. C., FOLLIOT R., RAVAULT J. P., 1985. Effects of gossypol tetra-acetic acid on testicular, epididymal and pituitary function of the rat, 661-669. In CHANG H. M., YEUNG H. W., TSO W. W., KOO A., Advances in chinese medical materials research, World Scientific Singapor-Philadelphia.

JEULIN C., SOUFIR J. C., MARSON J., PAQUIGNON M., DACHEUX J. L., 1987. The distribution of carnitine and acetylcarnitine in the epididymis and epididymal spermatozoa of the boar. $J$. Reprod. Fert., 79. 523-529.

MÉNEZZ Y, 1976. Milieu synthétique pour la survie et la maturation des gamètes et pour la culture de l'œuf fécondé. C. R. Acad. Sci. (Paris), 282, D, 1967-1970.

OKO R., HRUDKA P., 1982. Segmental aplasia of the mitochondrial sheath and sequelae induced by gossypol in rat spermatozoa ; Biol. Reprod., 26, 183-196.

PEARSON D. J., TUBBS P. K., CHASE J. F. A., 1974. Carnitine and acylcarnitines, vol. 3, 1762-1764. In BERGMEYER H. U., Methods of enzymatic ana/ysis. Acad. Press, New York.

SOUFIR J. C., DANTEC M. C., JEGOU B., FOLLIOT R., 1984. Epididymal effect of gossypol. The Lancet, 14, 106-107.

WEISSBACH A., 1974. D-myo-inositol, 1333-1336. In BERGMEYER H. U., Methods of enzymatic analysis. Acad. Press, New York. 